\title{
A Study on the Symbolic Meanings of Jars
}

\author{
Seo, Seung Hee
}

\begin{abstract}
$<$ Abstract $>$
This study intends to investigate the characteristics of the jar and examine their symbolism in literature and further the symbolic meanings of the jars, which clients of various developmental tasks used during sandplay therapy. For middle-aged clients who had to go through an individuation process, the jar signified motherhood and femininity that bring a new change to an insecure relationship with the mother; or the waiting place where women spend long hours of patience and silence until their distress and torment are ripened and transformed. For adolescent student with the developmental task of reaching a rite of passage, the jar acts as a place for death and regeneration where independence from the mother is led to the growth of the ego. The jar represents new expectancy and hope. The jar serves as motherhood who embraces clients who were brought up by negative parents, and also as a vessel of the ego to encourage femininity to go on a journey for beautiful growth. This study is significant in identifying the various symbolic meanings of the jar.
\end{abstract}

Keywords : symbol, jar, sandplay therapy

* Professor, Department of Nursing, Gwangju Women's University(holyjoy4373@hanmail.net) Studied by academic research support, Gwangju Women's University 
Journal of Symbols \& Sandplay Therapy, Vol.10 No.1.

\section{I . Introduction}

It is impossible to directly face and recognize the universal, fundamental archetype which lies deep in the human heart and soul. Only when an archetype itself is manifested as images or symbols, or complexes or symptoms, it can be indirectly faced(Jung, 1971). Symbols function to link a profound, deep meaning in the spiritual world to the human consciousness. In that sense, archetypes cannot be definitely interpreted nor completely recognized(Rhi, 2011). Therefore, symbols express unknown meanings via images, but some meanings still remain unexplained(Lee, 1991). However, the symbol of unconsciousness appears as a dream, a daydream, a symbolic act, revealing his presence(Cooper, 1987).

The sandplay therapy established by Kalff helps clients resolve emotional problems which cannot be expressed in words by inducing them to create a psychiatric and symbolic scene using sand and figures(Homeyer \& Sweeney, 1998). The state of spirituality freely flows in a safe place of mother-child unity, and is expressed in a sand tray. What are suppressed in the unconscious are resolved and faced and thereby are brought into consciousness. In this case, therapists should keep track of their client's inner growth process and appreciate their respective works with a deep understanding of the world of symbols involving folktales and myths(Kim, 2005). A client's sand tray scenes are full of therapeutic and strong metaphors. Therefore, the scenes require interpretation, but it should be by the client himself or herself (Homeyer \& Sweeney, 1998). As a therapist, it is necessary to study the meaning of symbol through the image invited to the sandbox to understand the inner side of the client more.

With regard to this, understanding the symbolic meanings of jars used in sand trays is useful for therapists to experience their clients' inner world together. The jar was used as daily goods indispensable to common people from prehistoric ages, as storage vessels, utensils for rituals, musical instruments, and tea cups(Son, 2004; Song, 2004). The symbolism is often expressed through myths, folk tales, and fairy tales, and is expressed through works and life customs that contain spirituality(Neumann, 1974). Looking at the jar through various literary works and customs, it is a typical symbol of femininity(Ammann, 1991), which is considered to be a symbol of maternity, similar to that of a woman holding a child(Cooper, 1987). In 
addition, due to the natural characteristics of breathing, aging and transformation were used as emblems of desire for death and regeneration in terms of being used as a mausoleum or an oyster(Kim, 2016).

In sandplay therapy, jars can be a symbol of inner self-expression of clients of various ages, from elementary school children to middle-aged adults. For middle-aged man who are suffering from interpersonal discomfort due to lack of emotional sympathy, he need maternity and femininity. Middle-aged woman who is subjected to violence by negative mother, who is demanded of excessive responsibility, and who is troubled by anxiety and impatience in raising her son, is required to mature their internalities and transform them into new ones. In addition, a female college student who grows up between a young mother and a violent and immature father must experience control of feeding, interpersonal relationship, difficulty in career decision, and heal motherhood and femininity and go to the world with self control. Adolescent who does not rest for a while with excessive energy but have no confidence and feeling of inferiority should be able to dream of the future by transforming them into energy to concentrate, mature, and concentrate energy through death and regeneration during puberty. The elementary school children who are raised by the immature mother who has been abandoned by the man selected as a refuge must show the fear of separation anxiety and unfamiliar male, and the work of positive maternity is desperately needed. The jar also holds various symbolic meanings. For the researcher, the jar represented warmth, a friend, and others. Indeed, the researcher spent a lot of time alone at home in childhood.

In that sense, this study examines the characteristics of the jar and their symbolism in myths, religions and literature. Further, this study deals with how clients use jars in their sand trays and how the jars are represented, in order to help understand their symbolism.

\section{ПI. Consideration on the Symbolism of Jars}

\section{Characteristics of Jars}

Earthenware potteries and jars are containers and vessels that are made by baking 
Journal of Symbols \& Sandplay Therapy, Vol.10 No.1.

widely available clay in a kiln and are widely used in daily life for various purposes of cooking, storage, burial, etc. Their initial use is traced back to the Neolithic Era, when people started to settle down and farm. Earthenware potteries are divided into glazed and unglazed based on the presence and absence of a dark brown glaze. Earthenware jars refer to a long, curved gourd-shaped vessel with a narrow neck and bottom and a swollen belly. Jars are divided into wide-mouthed jars, long-necked jars, short-necked jars, and others depending on the shape of mouth and neck. In the beginning, potteries were used, but they gradually gave way to jars. The materials used to make these bowls or vessels are so various, including not only clay but wood, gold, silver, copper, and glass(Song, 2004).

The origin of potteries or jars in Korea are plain earthenware and red polished earthenware in prehistoric times. Plain earthenware is diverse in color, ranging from yellowish brown to light brown. Red polished earthenware is various types of ancient pottery with a red oxidized steel applied on the surface that is rubbed smoothly with clamshells or white pebbles(Jeong et al., 1999). The ancient Chinese used colored earthenware with geometric patterns on the surface of the curved body or red polished earthenware patterned with a straw rope or twisted yarn. Over time, copper jars were also made as utensils used in ancestral rites. In the Minoan civilization on the island of Crete and the Mycenaean civilization, the surface of jars was decorated magnificently with geometric patterns and animal designs. Jars used in ancient Greece feature mythological figures and scenes executed in black pigment on a red background, or red pigment on a black background(Song, 2004).

In terms of the process of making earthenware, the first step is to spread soil on the floor, sprinkle water on the soil to moisten it, wait till the water is absorbed into the soil, and pound the clay with a paddle. Then, this clay is gathered into a mass and pounded to filter out coarse sand or impurities. Kneaded and dried a little in the shade, the clay is pounded with a mallet and is made into the shape of a brick. It is hit onto the floor to make a plank shape. The plank-shaped clay board is put on the spinning wheel and smoothed by beating it with a paddle. In this case, the shape of earthenware is determined by the speed of revolution and motion of the hands(Son, 2004; Lee, 2015).

As to the function of earthenware jars, as the crystallized water contained in the wall 
of earthenware is drained out when it is baked at a high temperature of $1,200^{\circ} \mathrm{C}$ to $1,300^{\circ} \mathrm{C}$, pores are created to cause air to pass between the inside and the outside of the earthenware. These pores function to push the impurities formed inside to the outside, making it possible to store contents for a long time without decomposition and help appropriately ferment and age food(Jeong, 2008). The materials used to make jars were easily available anywhere such as soil, glaze, and firewood. For this reason, even ordinary people could commonly use them without any financial burden. Earthenware served many uses, including chamber pots, inkstones, braziers, ashtrays, and roof tiles as tools in daily life; incense burners, earthenware coffins, and funerary wares as ceremonial tools; and pottery drums such as jiljanggu and ongjangu as traditional musical instruments. In addition, earthenware was widely used in various fields of industry, such as a vessel containing excretions, a bottle of water for chicks, and a pot to store the short-arm octopuses just caught by fishermen(Lee, 2015). Further, decorated forms of pottery also emerged throughout its history, like Goryeo celadon or Joseon porcelain.

Jars for storage were used as crocks for soy sauce or other condiments, water pots and jugs, alcohol jars, rice jars, chamber pots, bathtubs, earthenware steamers, and jars for water filtering, etc. They also functioned as cooking utensils like saucers or bowls to store washed vegetables, vessels used for dish-washing, tiny bowls to contain vinegar and other liquids, vessels to transfer a small quantity of rice from a rice bin, and jars to contain alcohol for picnic. In addition, there were also lipped jugs designed to pour liquid more easily, large bowls to grind grain, jars of various sizes intended to salt fish and shellfish down, lids to cover the top of jars, fire pots in which coal or charcoal is burned, and bowls to contain human feces used to fertilize a field. Like this, jars appear to have no limits in applicability(Yoon, 1996; Song, 2004).

The characteristics of jars are the indispensable tools of everyday life and the symbol of the container to hold various foods and materials which made of earth during its long history. The outer shape of the jar has a long neck and convex abdomen, which is similar to the long neck and bustle of a woman, and is often used as a symbol of femininity and maternity(Cooper, 1987). In addition, the jars formed in the process of being heated and heated at high temperature can be regarded as a symbol of fermentation and aging and 
Journal of Symbols \& Sandplay Therapy, Vol.10 No.1.

transformation as a breathing containers.

\section{Jar as a Symbol}

\section{1) Holiness}

God formed("yatsar") the first human out of the dust of the earth. In this regard, the jar symbolizes transformation and creation of soil. The word "jar" was derived from "yatsar", the Hebrew word related to the meaning of creation in the Middle East and Israel. It was used to depict God's such creative activity and thus, signifies the divinity of God. During the late Joseon dynasty period, Catholics who were persecuted went up mountains to keep their faith. There, they engaged in the production and distribution of jars. This historical event also put an image of faith and further divinity to the jar. In this context, the jar represents uniqueness of the Catholic Church including the days of severe persecution and the first cardinal as well as personal introspection for spiritual growth(Joo, 2012).

In the food culture where fermented foods like Kimchi made of seasoned vegetables, soy sauce, and salted seafood occupy a pivotal position, platforms where crocks of sauces and condiments were placed served as a lifeline for family health and were traditionally regarded as the sacred ground for women. For example, on the day of making the fermented soybean paste or doenjang, women took a bath before starting it. And they put charcoal or red chili pepper on doenjang in an attempt to prevent anything that might bring a misfortune or the evil from coming near(Bae, 1993). The platform for soybean paste crocks was enclosed with a high pile of stones to separate it from others, and crocks were carefully arranged depending on their size. As such, women in the old days treated jars with their utmost sincerity and viewed them as sacred in some ways. If a difficulty arose at home, they prayed in front of a bowl of freshly drawn water at the platform. In addition, rituals were held at the platform for crocks on the day of a great family occasion or on a special holiday. The rite for the house site guardian deity in Chungcheong-do Province, in which people placed foods on the jar platform and prayed for good luck and peace because jars were considered to be sacred and virtuous, is a typical example of such custom(Seo, 2009).

In Myeongju-gun, Gangwon-do Province, people had a custom of turning an empty 
spinning wheel or tying silk threads here and there around the jar stand in the hope that their child who was away from home would return home safely. Meanwhile, after making soy sauce, they cut hanji(Korean traditional paper handmade from mulberry trees) with the shape of beoseon (Korean traditional socks) and then attached the beoseon-shaped paper upside down to the jar as a shamanistic practice to prevent sauce taste from changing and ward off evil spirits. Since it was believed that if sauce taste changed, the family's fortune would begin to ebb or a bad luck comes, people took care of jars with sincerity. Thus, they carefully chose the date of making soy sauce and hung a straw rope around the jar stand to set it apart from other mischievous things. By doing so, access to the jar stand was strictly restricted as it was regarded as a sacred place(Bae, 1993; Seo, 2009).

Thus, the jars not only use as a living tool but also give new meaning to the making and handling of it. God's creative activity of creating the first person is so sacred and noble, that Catholics engaged in dealing with Onggi by avoiding persecution have always thought that they are earthly creatures, I guess they did not want to forget the holiness. The jars are seen as a symbol of the sacredness considering that the place where the jar is located where mother prayed and desired for the children. She is managed for all the jar full of the Jangdogdae.

\section{2) Motherhood and Femininity}

The jar stand and jars, as the most important sanctuary for women in the old days, were the places where only women could enter and worked. In this regard, there is a saying, "The husband is a well bucket and the wife is a jar." It means that a husband goes out and earns money, while a wife keeps money and manages a household(Korean Proverb Dictionary Compilation Committee, 2001). This proverb seems to imply that the femininity of the wife is treasured and productivity is promoted as the role of the wife.

The shape of jars usually resembles a woman's body as they are gently curved and look ample. In particular, Moon Jar, a form of traditional Korean white porcelain made during the Joseon Dynasty, is purely white-colored and well-rounded. As the feminine shape and milky color are reminiscent of the full moon, this jar came to be called "moon jar". The round 
Journal of Symbols \& Sandplay Therapy, Vol.10 No.1.

shape, in particular, shows a perfect balance between heaven and earth, or between yin and yang (Park, 2002)(Fig. 1). In addition, the feminine shape of Moon Jar seems to reflect a wish to heal and embrace social agonies and torments amid continuous wars and confusion in the Joseon Dynasty, as if they were in a mother's arms.

In The Broken Jug(Der zerbrochene Krug), a play by German Romantic writer Heinrich von Kleist(1777 1811), the jar is expressed as a symbol of women, and the broken jar is a metaphorical expression of the heroine Eve who loses her virginity(Heinrich, 1808). Femininity and motherhood manifested in the jar are also seen in paintings. White Jars and Women, a painting by the Korean abstract artist Kim Whan-gi(1913 1974), depicts women's strong will to survive without giving up hope, love, and dream amid the Korean War(Fig. 2). This inner strength is manifested in the jars on their heads or in their arms. Their image reminiscent of goddesses also seems to imply that women's tireless survival power to endure refugee life of distress may be linked to motherhood as a symbol of prosperity and vitality(Lee, 2015).

It seems to resemble the lavish appearance of women in appearance in general characteristics of the jar, symbolizing femininity and maternity, and the moon jar shows more women and maternity in symbolism as well as appearance. The moon is a typical natural object that means femininity. The fact that the moon is shaped like a moon seems to emphasize duality of femininity and maternity. In addition, the social confusion caused by the war gives anxiety and fear, but as a way to improve and heal it, the pot is expressed as a work of art as a symbol of motherhood and femininity.

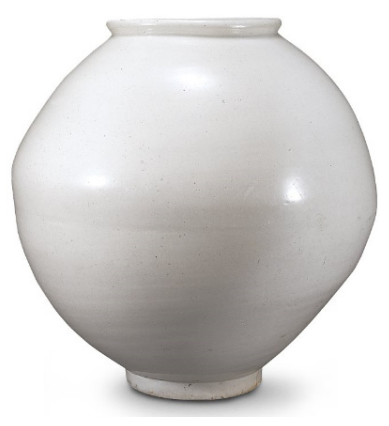

Fig. 1. Moon Jar

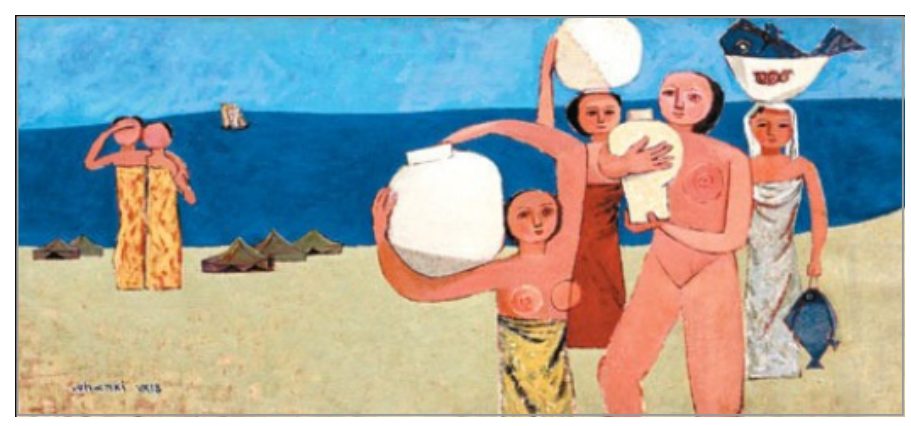

Fig. 2. White Jars and Women 


\section{3) Death and Regeneration}

One of the products from the Bronze Age is onggwanmyo(jar-coffin interments). The jars used as a coffin in earthen tombs prevailed in the period of the Three States. The name differed depending on the number of jars used. The form of a single jar with a wide and flat stone (lid) on the top was called "oedok"; and the form of two jars laid mouth to mouth was called "ieumdok". In Yeongnam districts, tombs uncovered around Nakdonggang River, the eastern coast, and Gyeongju show different tomb furnishings depending on social status, along with earthenware jars(Lee, 2011).

In ancient Greece and Rome, the remains left after a dead body was cremated were kept in a specially-crafted jar. In particular, the burial urn had mythological scenes exquisitely executed in red pigment on a black background that symbolizes death. Such mythological scenes seemed to have been painted in the hope that the mythological or legendary settings, or the immortality of the soul, would be connected to personal lives. That is, the wish for regeneration after death was embodied in burial jars(The Compilation Committee for Dictionary of Korean Myths and Symbol, 1996).

The jar as a symbol of death differs from the shape of the jar in that it contains the remains of the dead or the dead. Death is a new beginning, and it also means beginning in a new world. Therefore, the mausoleum used from the Bronze Age and the remains of ancient Greek Romans are enough to reveal the symbol of death and regeneration.

\section{4) Expectancy and Hope}

The story of Elijah in the Old Testament highlights such symbolism of the jar. Elijah visited a widow at Zarephath who was raising a son in a severe famine. He unabashedly took a small loaf of bread away from the widow. In fact, the widow was going to eat it with his son and die together. And then, Elijah said to the widow, "the jug of oil will not run dry until the day the Lord sends rain on the land." Thus, whenever she kneaded flour and made a loaf of bread using the oil in the jar, the widow would hope that the jar of oil would not be used up. Meanwhile, the woman of Shunem from the story of Elisha in the Old Testament could not help but send her two sons as slaves because of severe poverty. So, the widow came 
Journal of Symbols \& Sandplay Therapy, Vol.10 No.1.

to Elisha and asked for help. Elisha instructed her to borrow as many empty jars as she could from her neighbors, and to pour a very tiny amount of olive oil left in each jar into a jar. Surprisingly, she could fill one after another. For the woman in danger of losing her sons, the jars filled with oil mean expectancy and hope.

In Greek and Roman mythology, Pandora is known to be the first female human and be the human who released all the evils of humanity. In keeping with her name Pandora, meaning "an all-gifted woman", each god gave her unique gifts such as beauty, a skill for weaving, a gold crown, desire and worry, seducability, etc. Pandora was told to never open the jar in the house of Epimetheus who loved her, but she could not resist peeking into it out of curiosity. Upon opening it, all evils including diseases, aging, pains, and toils were unleashed into the human world. She tried to close the lid but it was too late. However, hope remained inside the jar. Hope provides humanity with expectancy of a better life, which would act as a source of power to live on(Moon, 2007).

The oil-filled jar in the Bible shows that life has been enriched by turning into hopes and hopes that can be transformed into life-sustaining forms. In Greek mythology, Pandora's jar would not have been able to enthrall the woman's curiosity before the box was opened, and through the hope that has already been left, Pandora's box jar still seems to reveal the symbol of hope and hope. The researchers also wondered what would happen every time they opened a jar in their childhood and there are some experiences that they expected.

\section{5) Maturement and Transformation}

The jar is a space where fermentation and maturement take place. The pores formed due to the jar's property functions to push impurities out and prevent moisture so that salted seafood, fermented soybean paste, and kimchi can be appropriately fermented, matured, and stored (Jeong, 2008). Maturement is a process in which food contained in a jar is degraded by microbes or enzymes to have a different chemical property, which leads to a palatable taste and a delicious smell. The maturement and transformation also prevent soy sauce in a jar from turning sour for a long time; and purify the water in a jar(Jeong et al., 1991). 
The Marriage Feast at Cana, which is known as the first miracle attributed to Jesus in the New Testament, is also a typical example showing this symbolism. When Jesus was invited to a wedding and the wine ran out, Jesus ordered the servants to fill jars with water and take them to the banquet, without the maturing process. And then, Jesus delivered a sign of his glory by turning water into the best wine. This event is a metaphor for various things(Park, 2009). Above all, however, the jar was used as a tool to transform water. As such, the jar is formed by a unique manufacturing process, so the contents are stored for a long period of time and can be seen not only to be damaged but also to be converted into new components. The jar serves as a symbol to embrace the human inner world and help enrich human life with a valuable experience of endurance and a mature attitude towards life.

\section{6) Container}

Storage means the act of storing and keeping something for future use. The jar in the old days of Korea was very diverse in purpose ranging from jars of honey to chamber pots to contain excrement. Jars were widely used to contain and keep almost everything necessary for daily lives. In particular, jars of different sizes and shapes served important functions on a jar stand and in a kitchen, like a storeroom. In addition to four jars for condiments-salts, sesame seeds, red pepper powder, and garlic cloves, there were water jars to draw water, a life-giving water, from the well, and jars to contain various fermented foods and drinks. In addition, jars were used to contain feces and urine or a dead body as a coffin. Indeed, jars could be used in many ways(Yoon, 1996).

The symbol of the jar as a container is the most primitive and functional. The shape of the jar is convex and bulky because of the nature of the jar. The purpose of using the primitive jar, as revealed in the comb pattern earthenware, Therefore, the symbolism of the container can be regarded as the most basic and important symbol of the jar. 
Journal of Symbols \& Sandplay Therapy, Vol.10 No.1.

\section{Symbolism of the Jar in Sandplay Therapy}

\section{Case of a Middle-aged Man: Motherhood and Femininity}

The sand tray scene in Fig. 3 was created by a 46 years old man who was suffering from conflicts with his adolescent son. As the youngest child between his mother who had toiled and moiled to support her family but lacked communication with her children and his father who was taciturn, the client had difficulty forming an attachment relationship with his parents in his childhood. In particular, the client was tormented by his growing anger at his son, onto whom he projected his shadow, and also felt anxious in personal relations. The belief that he should not cause trouble or inconvenience to others and the sense of excessive responsibility he had as a man resulted in him having a low self-esteem and a negative self-belief. In addition, the fear that the other two children might also treat him rudely, like his adolescent son, led to his conflicts with the child, making himself feel more depressed.

Fig. 3 shows the sand tray scene from Session 1 out of a total of 27 sessions. The middle-aged man arranged jars side by side in a rural scenery. This tray scene seems to imply the initiation of the work on motherhood. The men in this tray look full of energy of a boy but are standing in completely different directions without any interaction with one another. The work on motherhood, which would act as the power to promote relationships, is expected

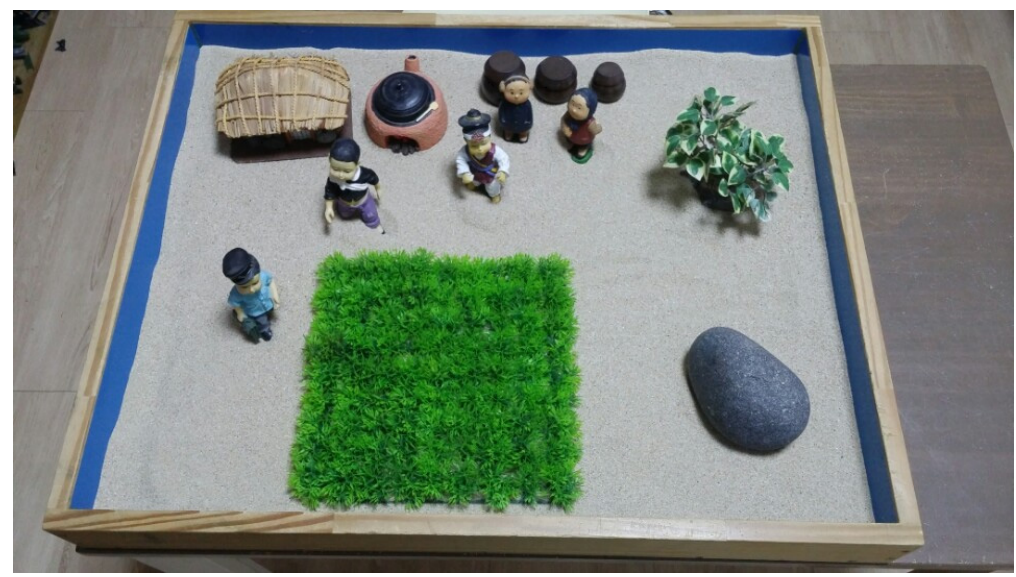

Fig 3. Session 1 
to lead to interactions between boys. The growth from a boy to an adult male, or the growth of the ego, will be motivated by the power of motherhood, which is in the jars.

The client, who has not enough emotional support and caring in the relationship with mother, experiences negative tension and frustration of interpersonal relationship. And her psyche is stimulated by the shadow through the son toward the Individualization process. In the therapeutic process, his spirituality appeared as an overly big tree with large shadows through several sessions. Then he could recognize his dark and rough shadows. And his femininity (anima) was revealed as a symbol of grief. As the treatment proceeded, his femininity changed into a positive feminine, passionate and enjoyable of life, and the change of femininity could be more comfortable in relation to men. During the 27 sessions, the maternity and femininity symbolized by the jar turned out to be positive femininity and to deal with emotions and interpersonal relationships.

\section{Case of a Middle-aged Woman: Ripening and Transformation}

The sand tray scene in Fig. 4 was created by a 42 years old woman who found herself excessively controlling her eight-year-old son and interfering in his affairs, thus making him feel frustrated and exhausted. The client was raised by her mother who was always busy at work all day long because she did not want to leave her children in poverty. Her mother entrusted a heavy responsibility to the client as the oldest daughter, often scolded her, and even hit her when she was young. In addition, the client's mother frequently boasted about how intelligent the client was to people in neighborhood, saying, "My daughter is so smart, she can do anything!", which put a big burden on her. After marriage, child rearing was mentally and physically demanding for the client. One day, the client was so stressful that she severely hit her three-year-old son in a toilet. Recently, the client became anxious about and sensitive to what was happening to her son at his elementary school. She sometimes ran to school and scolded him. So, her son finally was depressed and exhausted, and his psychological state surprised the client a lot. Thus, she began to receive this counseling with a sense of guilt.

The Fig. 4 shows the sand tray scene from Session 15 out of a total of 29 sessions. 


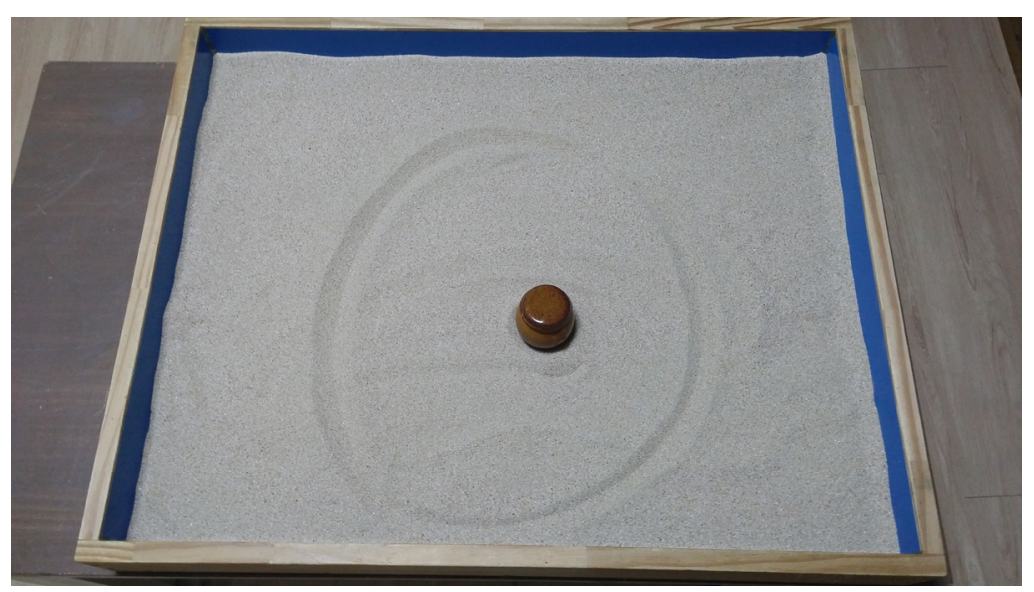

Fig. 4. Session 15

The client placed a jar in the center, drew a boundary around it, and called the jar a "breathing jar". It seemed that the client put a whirlpool of emotions into the jar, closed the lid, and then had time for patience with great sincerity. The time for patience with tears will be followed by time for fermentation, ultimately leading to rebirth. With a long wait in silence, she is hoping to put her own agony and distress in the jar and approach her son with a warm heart.

It is not easy for the client to nurture a son with the tendency to be trapped in negative motherhood, have a sense of tension and burden, and always have to accomplish work in time. Excessive control and unhealthy maternity negatively affected the formation of attachment, so that she can not control their emotions and also keep his feelings from being filled. Through the therapeutic process, the client was able to control the emotions by exposing the wounds of the tears, repeated process of putting emotions in the therapist and the sand box. As the result, her son was also energized and well adapted to school, and she was able to nurture with a more relaxed mind. The jar of the 15th session seems to spend the time of maturation and transformation waiting for the new birth of the client's feelings and sick wound. The inner side of the client who can not rest comfortably even when her life is stressed out seems to be going to the time of chemical change and transformation that is now breathing. 


\section{Case of a Female College Student: Motherhood and Femininity}

The sand tray scene in Fig. 5 was created by a female college student who felt depression and fear before new challenges that she would have to face after upcoming graduation. The client was born as the eldest daughter between her mother who was pregnant with her at an early age and remained poor at raising her until now and her immature father who neglected his family and often used violence. The client felt guilty towards her mother as her birth forced her mother to give up her free life and live together with her husband who was always negative. Such ambivalence led the client to look after her little sister and mother. Thus, the client was tormented by strong resentment toward her father and the fear that her mother might leave her, which led to difficulties in food intake control, interpersonal relationships, and career decision.

The Fig. 5 shows the sand tray scene from Session 50 out of a total of 51 sessions. The client, who had endlessly touched cold sand, shedding tears and feeling sorry for herself, no longer stood sadly in the middle of cold winter. The cold motherhood was turned into warm and positive motherhood and femininity, which seemed to be contained in the jars. The femininity led the client to take care of her appearance and emotions and challenge to have a blind date. With her positive motherhood, the client started to be interested in food intake control and maintain more comfortable relationships with the outside world.

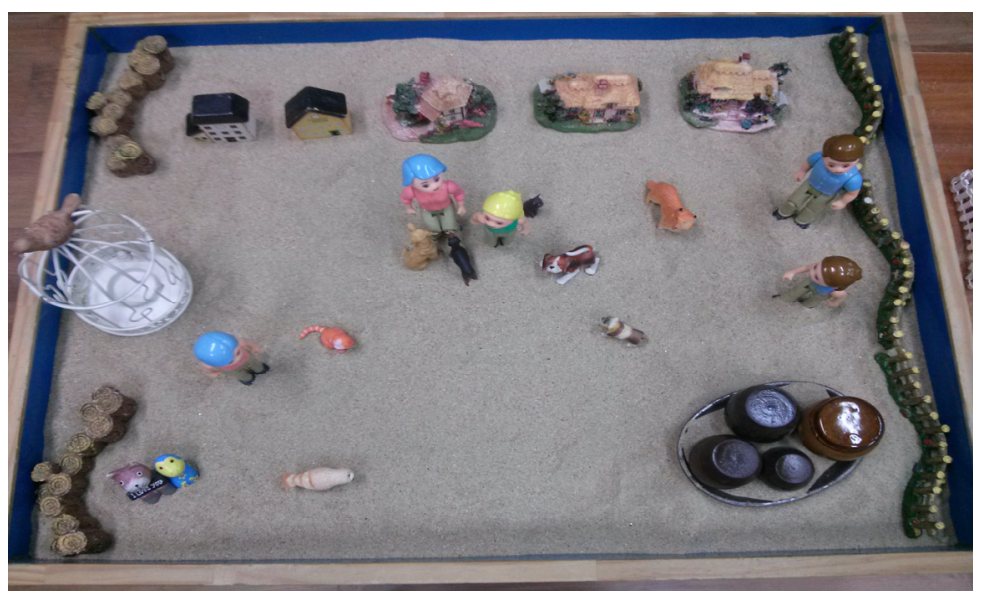

Fig. 5. Session 50 
Journal of Symbols \& Sandplay Therapy, Vol.10 No.1.

The client is afraid of going out into the world surrounded by depression and helplessness due to negative motherhood and fatherhood. Her inside is cold, femininity as a dwarf and maternity like a mermaid are in a regressive, cold and infantile stage, so they have difficulties in reality.

4. Case of an Adolescent Boy: Fermentation and Ripening, Expectancy and Hope, Death and Regeneration, and a Container

The sand tray scene in Fig. 6 gives an impression of excess energy, but it was created by a 13 aged adolescent boy who always lacked confidence with a sense of inferiority. The client was born and grown up between his father who was too shy to express himself and his mother who was so self-assertive and energetic that she dropped out of high school when she was young. His tendency to keep moving, from early childhood, made his mother feel anxious. During his school years, he was so seriously afraid of examinations that he frequently said he would fail in the examinations from a month before the date of examinations. When it comes to peer relationship, he hesitated to speak his mind. He was overly obsessed with games. Usually, the client thought he was inferior to his older sister, thus making his parents worry about him.

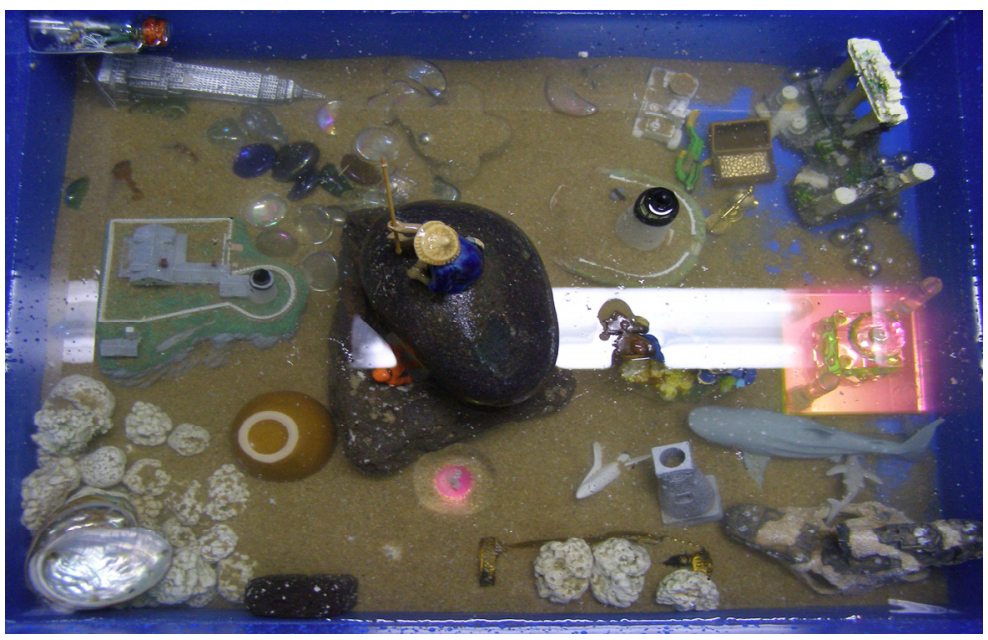

Fig. 6. Session 20 
The Fig. 6 shows the sand tray scene from Session 20 out of a total of 96 sessions. The excess energy contained in the jar was buried deep under the sea. This suggests that the client was going through a rite of passage through death. The angler, sitting in the center of the mind, hung a fishing rod in the hope that the energy contained in the jar would be regenerated and transformed into fish of wisdom and the ego so that he could catch them. The fish which were caught in this way were put into the jar again and went through ripening and transformation, which would provide a new opportunity to deal with feelings of anxiety and inferiority and adequately control energy. In the sand tray scenes created by adolescents, the jar holds various symbolic meanings including fermentation and ripening, expectancy and hope, death and regeneration, and a container.

The client finds his identity and has the task of career and independence, but he feels uneasy and uneasy feelings to the mother and the excessive energy is always uncontrolled and overflowing. The client repeatedly attempted to achieve the centralization of spirituality by exploring the unconscious world endlessly, confronting what the boy explorer, the self-image, was trying to capture himself in the deep inner mother's excessive care. Many frequently used pots are used as a tool to transform hope and expectation, sometimes death and regeneration, through fermentation and aging in containers filled with sand, fruit, and beads. Figure 6, Atlantis in the deep sea filled with Pharaoh's cisterns and minerals. It is in the deep sea for a long time and the client does not stop exploring in a world of water. At present, the client has decided to set his course as a missionary, concentrating his energy, and preparing for his life.

\section{Case of an Elementary School Girl: Motherhood}

The sand tray scene in Fig. 7 was created by a girl in the first grade of elementary school who had separation anxiety and a fear of adult males while being raised by an insecure single-parent family. The client's mother was born from her alcohol-dependent father and her feckless mother. Wanting to escape from her parents as quickly as possible, she began to live together with a man without getting married. When she was pregnant with the client and gave birth to her, the man abandoned and left them. As she was alone only with her 


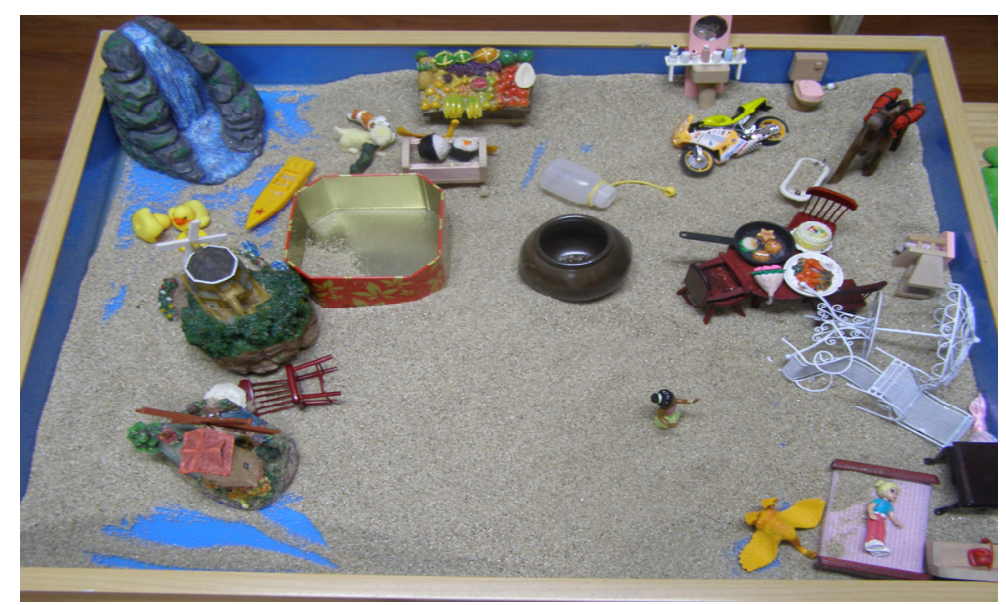

Fig. 7. Session 28

three-year old daughter, she always said to the client, "You must not trust men in the world at all." As a result, the client began to feel uneasy and thus endlessly muttered something to herself. In addition, she felt anxiety about separation from her mother. After entering the elementary school, she cried heavily out of terror whenever meeting the eyes of any strange man on the way to school. So, her mother had to accompany her to school. Sometimes, the client did something like masturbation.

The sand tray scene in Fig. 7 is from Session 28 out of a total of 31 sessions. The client called the tray of this session "happy house". Throughout the sandplay therapy process, the client tended to show performances of releasing strong aggression and emotions, which are interpreted as an attempt to strengthen the ego. Although the house was littered with garbage, the jar placed as a symbol of motherhood in the middle of the house seems to function to push negative emotions and motherhood out of the house and store clean, virtuous emotions and motherhood.

The child was not developing consciousness due to negative motherhood and insecure attachment, and shows problems of depression, anxiety, externalization and adaptation to school life is not easy. Therefore, she should be able to control his emotions and adjust to school through the stable and continuous nurturing through performance and food intake. She tried to strengthen my inner self through the performance of the house with the panda bear and the bed, the play of the house, and the activity of eating the food in the canister and eating it in 
the canister in a stable and therapeutic space. In reality, the mother of the child changed her consultation time freely, and after a few minutes of the therapeutic performance, she asked the child to come out promptly by knocking on the door of the counseling room. Figure 7 shows that a therapist(a black girl) is eaten by eating a bird while eating, while a therapist(a black girl) It seems to be. At the time of closing, my child adapted to the school and went to school alone and spent time playing alone even though she could not see her home. She showed a change of inviting one friend at home.

\section{Conclusion}

This study examined the characteristics and symbolism of the jar widely used for multiple purposes as principal necessities in our daily lives and then the symbolic meanings of the jar shown in sand trays created by clients of different ages.

The symbolism of the jar can be summarized as follows. First, the jar represents holiness. God formed the first human out of the dust of the earth just as earthenware was made of clay. Catholics made jars to escape from persecution during the late Joseon dynasty period. Women in the old days regarded a jar stand as the sacred ground to keep the family health. Second, jars symbolize motherhood and femininity. The jar stand is the most important place for mothers to prepare some food vital for the life of their children. In addition, it is a space for women to put agonies and emotions. Third, the jar is a symbol of death and regeneration. In the Bronze Age, a dead body was contained in a jar-coffin(onggwanmyo) for interment. In ancient Greece and Rome, remains were kept in a specially-crafted jar with a wish for a new immortal life. The fourth symbolism of the jar is related to expectancy and hope. The widows in poverty and distress who met the prophets Elijah and Elisha in the Old Testament began to have a hope and an expectancy through the jar filled with oil. The jar in the hands of Pandora in Greek mythology provides expectancy and hope for a better life. Fifth, the jar represents maturement and transformation. The jar filters impurities out with pores and matures food in it through fermentation of microbes. The jar containing water at the Marriage 
Journal of Symbols \& Sandplay Therapy, Vol.10 No.1.

at Cana or Wedding at Cana, known to be the first miracle attributed to Jesus, enriches lives of humanity as it is transformed into wine. Sixth, the jar functioned as various kinds of useful containers to contain and store almost everything including grains, liquids, honeys, and even excrement.

To see how these symbols are expressed in sandplay therapy, we looked at the trays of clients at developmental stages. In Fig. 3, the jars are represented as the possible recovery of motherhood inside a middle-aged man who was struggling with his adolescent son and the difficulties of negative femininity. The middle-aged man who lacked an attachment to his mother and had difficulty in relationships was expected to recover the negative motherhood and anima through his son to whom his shadow was projected and then move on to the individuation process. In Fig. 4, the middle-aged woman, who excessively controlled and interfered her eight-year-old son, making him feel frustrated and exhausted, put a jar in the middle of the sand tray to represent her wish to maturate and transform herself. The heavy responsibility and emotional abuse, which the client experienced in the relationship with her mother in her childhood, swirled into negative emotions, and her serious emotional state badly affected her parenting. However, as she felt a sense of guilt, she wanted to expel such negative emotions out of her mind. In this regard, the breathing jar can be interpreted as pushing negative emotions out and waiting for ripening and transformation as positive energy and ego growth.

In Fig. 5, a female college student who was afraid of new challenges after upcoming graduation used jars as the symbol of motherhood and femininity. In the process, difficulties due to her immature mother's negative parenting were gradually replaced with energy. The client, who felt fear and anxiety that her mother might leave her, had the experience of motherhood involving touching sand and the unconscious process of putting sand into a jar, which was linked to the positive motherhood and femininity, and further leading to appropriate food intake control and changing appearances. In Fig. 6, the sand tray scene gives an impression of excess energy, but it was created by a middle school student who had a sense of inferiority and anxiety about examinations. In this case, the jar had various symbolic meanings such as ripening and transformation, which are experienced when one goes through a rite of 
passage, expectancy and hope, death and regeneration, and a container. Although the middle school student met death as he reached a rite of passage, the angler in the sand tray, sitting in the center of the spirituality, hung a fishing rod in the hope that the energy contained in the jar would be ripened and regenerated into fish of wisdom so that he could catch them. The fish, which were caught after a long wait in this way, would be put into the jar again.

In Fig. 7 , the jar was used as a symbol of motherhood, which patiently embraces anxiety, terror, and aggression of an elementary school student who had separation anxiety and a fear of adult males while being raised in an insecure single-parent family. The client experienced a sense of stability as she fully expressed her own aggression and confusion. In the process, her motherhood exerted power to maintain balance between the unconscious and the conscious, and the client tried to step forward towards positive motherhood.

As such, the clients revealed painful experiences from their childhood as the inner task and the journey for therapy in the sandplay therapy process. This study confirmed that the symbolism of the jar in literature as holiness, motherhood and femininity, expectancy and hope, death and regeneration, maturement and transformation, and a container could bring about therapeutic growth in clients. However, there was a limit to reveal the symbolism by introducing the one picture and case superficial analysis of the sandplay therapy to confirm the symbolism of the jar, and the case of the elementary school children seemed to be somewhat difficult to think that the sandplay therapy was effective. We propose further study that a study on the symbol of the jar by introducing the pictures of several sessions of one client in depth or the symbol of the jar that complemented the qualitative ones that can clearly reveal that the sandplay therapy was effective.

\section{References}

Amman, R. (1991). Healing and transformation in sandplay. Chicago: Open Court Publishing. (Trans, into Korean in 2009).

Bae, D. S. (1993). Folklore of jar stands. Korean Folkloristics, 25, 197-235. 
Journal of Symbols \& Sandplay Therapy, Vol.10 No.1.

Cooper, J. C. (1987). An illustrated encyclopaedia of traditional symbols. London: Thames \& Hudson. (Trans, into Korean in 1996).

Heinrich, V. K. (1808). Der zerbrechne krug. (Trans, into Korean in 2005).

Homeyer, L. E., \& Sweeney, D. S. (1998). Sandtray: A practical manual. London: Routledge. (Trans, into Korean in 2007).

Jeong, H. S. (2008). Pottery. Seoul: Yolimwon.

Jeong, Y. M. et al. (1991). Jars. Seoul: Daewonsa.

Joo, W. J. (2012). The potter who shaped body and mind- The effective history of the verbal root rcy-. Journal of Human Studies, (23), 105-146.

Jung, C. G. (1971). Man and his symbols. London: Aldus Books. (Trans, into Korean in 2009).

Kim, B. A. (2005). The theory and practice of sandplay therapy. Seoul: Hakjisa.

Kim, M. K. (2016). The study of symbolic meaning of pot in the sandplay therapy. Korean Journal of Sandplay Therapy, 12(1), 44-59.

Korean Proverb Dictionary Compilation Committee (2001). Korean proverb dictionary. Seoul: Yeogan Publishing.

Lee, C. S. (2011). A study on transition process of the jar coffins in Youngnam area from early iron age to proto-three kingdoms period. The Journal of Korean Ancient Times, 72, $87-124$.

Lee, H. S. (2015). Aspect of traditional knowledge in the production of jar. The Journal of Folklorism, 31, 299-333.

Lee, J. N. (1991). Meaning of symbolism in analytical psychology. Journal of Korean Neuropsychiatric Association, 30(5), 805-814.

Moon, H. G. (2007). The message and image of woman reflected on the pandora myth. The Journal of Classical Studies, 21, 67-87.

Neumann, E. (1974). Die Grosse Mutter. Dusseldorf: Walter. (Trans, into Korean in 2009).

Pak, G. H. (2002). The characteristics of Joseon White Porcelains of the 17th and 18th centuries. The Korean Society of Oriental Art Studies, 6, 85-117.

Park, J. S. (2009). Theological meaning of marriage feast at Cana: Focusing on John 2. The Journal of Kwangshin University, 18, 51-69. 
Rhi, B. Y. (2011). Analytic psychology. Seoul: Iljogak.

Seo, H. S. (2009). The rite of rice-enshrinement Korean Teoju faith and cultural regions. Journal of Local History and Culture, 12(2), 135-171.

Son, J. R. (2004). Traditional Onggi on the viewpoint of design. Korean Journal of Folk Studies, 14, 293-327.

Song, J. S. (2004), Korean jars. Seoul: Dongmunseon.

The Compilation Committee for Dictionary of Korean Myths and Symbols (1996). Dictionary of Korean myth and symbols. Seoul: Donga Publishing.

Yoon, Y. Y. (1996). Our beautiful jars. Seoul: Hakgojae.

$<$ Internet $>$

Lee S. H. (2015.6.16.) Aesthetician Lee, S. H. 'Adventure of image' <12>: Kim, H. G. 'White jars and women' jars which embrace split life. Retrieved from: http://www.kookje.co.kr/news2011/asp/newsbody.asp?key=20150617.22020184259 